FITRAH Jurnal Kajian Ilmu-ilmu Keislaman

Vol. 02 No. 2 Desember 2016

e-ISSN : 2460-2345, p-ISSN: 2442-6997

Web: jurnal.iain-padangsidimpuan.ac.id/index.php/F

\title{
APLIKASI MURABAHAH DALAM PERBANKAN SYARIAH
}

\author{
AMINAH LUBIS \\ Mahasiswa Pasca Sarjana UIN Sumatera Utara Jurusan Ekonomi Syariah
}

\begin{abstract}
Absract
One of the popular branches juris purdence applied in the Islamic Banking is murabahah tranding. The definition of murabahan in Sharia Banking is as financing in the form of buying and selling between banks and customers on installment. In the Sharia Banking, there are two forms of murabahah is generally applied, that is working capital of murabahah and murabahah investment. However, every Islamic Banking has the form of buying and selling goods the diverse whether it internal of murabahah or external of murabahah.The are eight forms of murabahah practice which are every bank has a different kind to the other bank. The implementation of the system murabahah in islamic banks have positive impact on all parties, both the bank and the customer, but in practice of operations, often found irregularities commited done by employes of some Islamic Banks.
\end{abstract}

Key Word: Application, Murabahah, Perbankang, Syariah

\begin{abstract}
Abstrak
Salah satu skim fikih yang populer diterapkan dalam perbankan syariah adalah skim jual beli Murabahah. Murabahah dalam perbankan syariah didefinisikan sebagai pembiayaan yang berbentuk jual beli antara bank dan nasabah dengan cara pembayaran angsuran. Dalam perbankan syariah, ada dua bentuk murabahah yang umumnya dipraktekkan, yakni murabahah modal kerja dan murabahah investasi. Namun, Setiap perbankan Islam mempunyai bentuk jual beli murabahah yang beraneka ragam baik itu murabahah internal, dimana pihak bank membeli barang dan komoditinya dari pasar dalam negri ataupun murabahah eksternal, dimana pihak bank membeli barang dan komoditinya dari luar negri (Import). Praktek murabahah ini sampai kepada delapan bentuk yang mana setiap bank memiliki bentuk yang berbeda dengan bank lain. Penerapan sistem murabahah pada bank-bank Islam pasti memberikan dampak positif kepada semua pihak yang terkait, baik pihak bank begitu juga dengan pihak nasabah. Akan tetapi dalam praktek operasionalnya sering terjadi beberapa penyimpangan yang biasanya dilakukan oleh oknum pegawai pada beberapa Bank Islam.
\end{abstract}

Kata Kunci: Aplikasi, Murabahah, Perbankang, Syariah

\section{PENDAHULUAN}

Perbankan bagi perekonomian modern telah melakukan apa yang telah dilakukan oleh cikal-bakal uang bagi perekonomian primitive ketika barter 
masih berlaku. Perbankan telah memudahkan pertukaran dan membantu pembentukan modal dan produksi yang berskala masal dalam sejarah umat manusia. Tetapi jejak-jejak yang ditinggalkan perbankan dalam melaksanakan hal-hal tersebut ikut bertanggungjawab atas momok-momok terbesar dalam perekonomian modern, tidak meratanya pembagian pendapatan dan kesejahteraan, konsentrasi kekuatan ekonomi, kecenderungan yang bersifat endemis ke arah inflasi dan proses akumulasi utang yang sangat cepat dalam beberapa sektor perekonomian dengan konsekuensi-konsekuensi sosial, politik dan ekonomi yang sangat serius. Oleh karenanya sistem ini menghendaki penelitian yang seksama untuk menyokong suatu perombakan dasar dalam perbankan yang akan menyingkirkan penyakit-penyakit ini serta mengarahkan sistem ini kepada keadilan untuk seluruh umat manusia.

Maka munculah suatu sistem perbankan syariah yang menjadi sebuah solusi yang mungkin ditempuh untuk menyelamatkan perekonomian dunia yang sedang mengalami goncangan krisis global. Perbankan syariah seakan hadir menjawab keraguan akan perbankan konvensional yang tidak kunjung memperbaiki perekonomian dunia umumnya dan Indonesia pada khususnya.

Salah satu tonggak penting dalam pengembangan ekonomi syariah di Indonesia adalah beroperasinya Bank Muamalat Indonesia pada tahun 1992. Perbankan Syariah semakin marak mana kala diterbitkannya UU No. 10 Tahun 1998 yang memungkinkan perbankan menjalankan dual banking system atau bank konvensional dapat mendirikan divisi syariah. Dengan adanya Undang-undang tersebut bank-bank konvensional mulai melirik dan membuka unit usaha syariah. Tak heran jika perkembangan perbankan syariah cukup pesat. Dalam kurun waktu 15 tahun perbankan syariah secara keseluruhan terdiri dari 3 Bank Umum Syariah, 25 Unit Usaha Syariah dan 109 BPRS. Penambahan kuantitas tersebut diimbangi oleh penetrasi jangkauan layanan. Sebelumnya pada bank maupun unit syariah hanya boleh melayani calon nasabah di kantor cabang syariah atau kantor cabang pembantu. Namun sejak office channeling yang didasari Peraturan BI Nomor 8/3/PBI/2006 dan berlaku efektif Mei 2007 pelayanan jasa financing, seperti pembukuan rekening, setor, transfer, kliring dan tarik tunai bisa dilakukan di cabang bank umum yang mempunyai unit syariah. Dengan penerapan office channeling ini, akselerasi pertumbuhan bisa segera terealisasi. 
Sejak awal tahun 1984, di Pakistan, pembiayaan jenis murabahah mencapai sekitar delapan puluh tujuh persen (87\%) dari total pembiayaan dalam investasi deposito PLS. Sementara itu, di Dubai Islamic Bank, pembiayaan murabahah mencapai delapan puluh dua persen $(82 \%)$ dari total pembiayaan selama tahun 1989. Bahkan, di Islamic Development Bank (IDB), selama lebih dari sepuluh tahun periode pembiayaan, tujuh puluh tiga persen $(73 \%)$ dari seluruh pembiayaannya adalah murabahah. ${ }^{1}$ Sementara itu, hasil penelitian di BMI Semarang pada tahun 1999, sekitar tujuh puluh delapan persen $(78 \%)$ dari total pembiayaannya adalah pembiayaan murabahah. Padahal, sebenarnya bank syariah memiliki produk unggulan, yang berbasis Profit and loss sharing (PLS), yaitu mudharabah dan musyarakah.

Meskipun demikian, mekanisme pembiayaan murabahah ini, ternyata tak lepas dari kecaman dan kritikan dari para Ilmuwan Muslim sendiri. Mereka berpendapat bahwa bank-bank syariah dalam menjalankan kegiatan usahanya, ternyata bukannya meniadakan bunga dan membagi resiko, tetapi tetap mempertahankan praktek pembebanan bunga, namun dengan label 'Islam'. ${ }^{2}$ Di kalangan Ulama Fiqih pun, keabsahan pembiayaan Murabahah-pun masih debatable. Ada sebagian ulama yang membolehkan karena murabahah merupakan jual beli, tetapi ada sebagian ulama yang melarang karena beranggapan bahwa murabahah itu bukanlah jual beli melainkan hilah untuk mendapatkan riba. Ada sebagian ulama yang menganggapnya sebagai bai' al$i_{n a h^{3}}$ yang haram hukumnya, ada sebagian ulama yang menganggapnya sebagai bai' al-ma'dum, dan ada pula yang menganggapnya sebagai ba'iatani fi bai'ah. ${ }^{4}$

Adapun dalam tulisan ini akan dibahas bagaimana praktek dari salah satu produk bank syariah ini, yang banyak diminati masyarakat sekarang. Suatu bentuk investasi yang dilahirkan oleh sistem perekonomian Islam, bentuk produk ini bukan hanya menjadi salah satu instrumen ekonomi yang vital dan strategis namun juga rentan sekali dengan polemik-polemik dan penyelewengan

\footnotetext{
${ }^{1}$ Abdullah Saeed. Islamic Banking and Interest, A Study of Prohibition of Riba and Contemporary Inter -pretation (Leiden: 1996 E.J.Brill) hlm. 77

2 Sutan Remy Sjahdeini. Perbankan dan Kedudukannya dalam Tata Hukum Perbankan Indonesia (Jakarta: Pustaka Utama Grafiti, 1999) hlm. 17.

${ }^{3}$ Rafi Yunus Al-Misri. 1991. Al-Jami' fi Ushul ar-Riba (Damaskus: Dar al-Qalam, 1991) hlm. 172

4 Yusuf Qardhawi. Bai' al-Murabahah li al-Aamir bi as-Syira'Kama Tajriyhi al-Masharif alIslamiyah. (T.tp: Maktabah Daru al-Qalam, 1994) hlm. 26
} 
FITRAH Jurnal Kajian Ilmu-ilmu Keislaman

Vol. 02 No. 2 Desember 2016

yang diakibatkan dari keterbatasan sumber daya manusia yang dimiliki perekonomian Islam.

\section{KAJIAN TEORITIS}

\section{Murabahah dalam Perbankan Islam}

Salah satu skim fiqih yang populer diterapkan dalam perbankan syariah adalah skim jual beli Murabahah. Murabahah dalam perbankan syariah didefinisikan sebagai pembiayaan yang berbentuk jual beli antara bank dan nasabah dengan cara pembayaran angsuran. Dalam perjanjian murabahah bank membiayai barang atau asset yang dibutuhkan oleh nasabahnya dengan menambahkan suatu mark-up atau margin keuntungan. Dengan kata lain penjual barang dari bank ke nasabah dilakukan atas dasar cost-plus profit. ${ }^{1}$

Dalam perbankan syariah, ada dua bentuk murabahah yang umumnya dipraktekkan, yakni murabahah modal kerja dan murabahah investasi. Penjelasannya sebagai berikut :

a. Murabahah modal kerja adalah akad jual beli antara bank selaku penyedia barang dengan nasabah selaku pemesan untuk membeli barang. Dari transaksi tersebut bank mendapatkan keuntungan jual beli yang disepakati bersama. ${ }^{2}$ Atau menjual suatu barang dengan harga asal (modal) ditambah dengan margin keuntungan yang disepakati dan biasanya pembiayaannya ditangguhkan dibawah satu tahun (short run financing). ${ }^{3}$

b. Murabahah investasi, yaitu suatu perjanjian jual beli untuk barang tertentu antara pemilik dan pembeli, dimana pemilik barang akan menyerahkan barang seketika sedangkan pembayaran dilakukan dengan cicilan dalam jangka waktu yang disepakati bersama dan biasanya pembiayaannya diatas satu tahun (long run financing) ${ }^{4}$

Rukun murabahah dalam perbankan (sama dengan fiqih dan dianalogikan dalam praktek perbankan):

a. Penjual $\left(b a^{\prime} i\right)$ dianalogikan sebagai bank.

b. Pembeli (musytari) dianalogikan sebagai nasabah.

${ }^{1}$ Sutan Remy Sjahdeini. Perbankan (Jakarta: Pustaka Utama Grafiti, 1999) hlm. 76.

${ }^{2}$ Arison Hendry, Perbankan Syari'ah: Perspektif Praktisi, (Jakarta: Mu'amalat Institute, 1999), hlm. 43 .

${ }^{3}$ Karnaen Perwaatmadja, MPA. H. Muhammad Syafi'I Antonio, M.Ec. Apa dan bagaimana bank Islam (Yogyakarta: Dana Bhakti Wakaf, 1992) hlm. 25-26

${ }^{4}$ Karnaen Perwaatmadja, MPA. H. Muhammad Syafi'I Antonio, M.Ec. Apa dan bagaimana bank Islam (Yogyakarta: Dana Bhakti Wakaf, 1992) hlm. 27 
c. Barang yang diperjualbelikan (mabi'), yaitu jenis pembiayaan seperti pembiayaan investasi.

d. Harga (tsaman) dianalogikan sebagai pricing atau plafond pembiayaan.

e. Ijab Qabul dianalogikan sebagai akad atau perjanjian, yaitu pernyataan persetujuan yang dituangkan dalam akad perjanjian. ${ }^{1}$

Adapun Syarat-syarat umum dari murabaha adalah:

a. Pihak yang berakad

1) Adanya kerelaan kedua belah pihak

2) Memiliki kemampuan untuk melakukan jual beli

b. Barang atau obyek

1) Barang itu ada meskipun tidak di tempat, namun ada pernyataan kesanggupan untuk mengadakan barang itu.

2) Barang itu milik sah penjual atau seseorang

3) Barang yang diperjualbelikan harus berwujud

4) Barang itu tidak termasuk kategori yang diharamkan

5) Barang tersebut sesuai dengan pernyataan penjual

6) Apabila benda bergerak, maka barang itu bisa langsung dikuasai pembeli dan harga barang dikuasai penjual. Sedangkan bila barang itu tidak bergerak dapat dikuasai pembeli setelah dokumentasi jual beli dan perjanjian atau akad diselesaikan.

c. Harga

1) Harga jual bank adalah harga beli ditambah keuntungan

2) Harga jual tidak boleh berubah selama masa perjanjian

3) Sistem pembayaran dan jangka waktunya disepakati bersama

Selanjutnya syarat-syarat khusus murabahah adalah sebagai berikut:

a. Penjual hendaknya menyatakan modal yang sebenarnya dari barang yang hendak dijual.

b. Kedua belah pihak (penjual dan pembeli) menyetujui besarnya keuntungan yang ditetapkan sebagai tambahan terhadap modal sehingga modal ditambah dengan untung merupakan harga barang yang dijual.

c. Barang yang dijual secara murabahah dan harga barang itu bukan dari jenis yang sama dengan barang ribawy yang dilarang diperjualbelikan kecuali dengan timbangan atau takaran yang sama. Dengan demikian tidak sah jual hlm. 43 .

${ }^{1}$ Arison Hendry, Perbankan Syari'ah: Perspektif Praktisi, (Jakarta: Mu'amalat Institute, 1999), 
FITRAH Jurnal Kajian Ilmu-ilmu Keislaman

Vol. 02 No. 2 Desember 2016

beli secara murabahah atas emas dengan emas, perak dengan perak, gandum dengan gandum, beras dengan beras dan bahan-bahan makanan lainnya yang jenisnya sama. ${ }^{1}$

\section{Bentuk-Bentuk Murabahab dalam Perbankan Syariah}

Setiap perbankan Islam mempunyai bentuk jual beli murabahah yang beraneka ragam baik itu murabahah internal, dimana pihak bank membeli barang dan komoditinya dari pasar dalam negri ataupun murabahah eksternal, dimana pihak bank membeli barang dan komoditinya dari luar negri (Import). Dan dibawah ini akan dijelaskan beberapa praktek murabahah dalam keseharian perbankan Islam dengan catatan ada beberapa bentuk murabahah yang dipraktekan oleh salah satu bank akan tetapi tidak dipraktekan di bank lainya (tergantung kondisi dan kebijakan investasi), dan juga ada beberapa penyimpangan yang telah melanggar norma syariah, tergantung moralitas pelaku bank tersebut ketika merealisasikan produk murabahah ini.

\section{a. Bentuk Pertama}

Terjadinya kesepakatan antar pihak klien (yang ingin membeli barang) dan pihak bank (yang mempunyai barang dan ingin menjualnya) untuk melakukan transaksi jual beli dengan harga pembelian awal (harga beli pertama dan ongkos pengadaan), dan pembayarannya dengan cash atau kredit (tergantung kesepakatan), ditambah margin sebagai keuntungan pihak bank. ${ }^{2}$

\section{b. Bentuk Kedua}

Pihak klien meminta bank untuk membelikan suatu barang dengan sifat, tanda dan harga yang telah ditentukan (pihak klien), dengan kompensasinya pihak pembeli (klien) akan membayar harga tambahan (selain biaya pembelian dan pengiriman) sebagai upah kerja pihak bank dalam mendatangkan barang yang dipesannya.

Bentuk ini telah diajukan Bank Dubai al-Islam pada muktamar pertama perbankan Islam yang diselenggarakan di Dubai pada tanggal 22 Mei 1979, kemudian muktamar memutuskan bahwa praktek seperti ini disebuk wikalah bi ajirin (perwakilan dengan imbalan) dan mengategorikannya sebagai perwakilan dalam transaksi jual. Selain itu muktamar juga menmeberikan

1 Tazkia Institute, Murabahah, Makalah disampaikan pada Program Pendidikan dan Pengembangan SDM Bank Mu'amalah, hlm. 2.

${ }^{2}$ Bait Attamwiel al-Kuwaity. Buyu' Al-amanah fi mizan al-syari'ah, (1983) hlm. 9 
rekomendasi dan anjuran agar upah yang diminta bank sesuai dengan standar upah yang berlaku di daerah tersebut. ${ }^{1}$

\section{c. Bentuk Ketiga}

Pihak klien meminta pihak bank untuk membelikan suatu barang dengan sifat, tanda dan jumlah yang telah ditentukan (oleh pihak klien) dan klien berjanji (Al-Wa'du Ghoiru Muljam) akan membeli barang tersebut apabila telah datang secara angsuran, ditambah margin untuk pihak bank.

Dan pihak klien boleh menentukan sumber (pabrik) barang yang dipesannya itu, atau ia cukup dengan menentukan sifat, tanda dan data-data yang yang dipesannya, dan memepercayakan pihak bank mencarikan barang tersebut dari mana saja dia mendapatkannya (yang penting sesuai dengan pesanan). Tapi dalam bentuk ini pihak klien tidak diharuskan untuk membeli barang tersebut, dia boleh membelinya apabila barang itu datang dan juga boleh menggagalkan pesanannya. ${ }^{2}$ Bentuk ini berbeda dengan bentuk (no: 5). Yang mengharuskan klien untuk membeli barang sebagai kewajiban janjinya.

Dari sini jelas bahwa transaksi ini mempunyai resiko tinggi, aplagi apabila klien membatalkan pembelian, sehingga pihak bank akan kesulitan memasarkan barang tersebut (khususnya pada barang yang mempunyai konsumen terbatas). Untuk mengantisipasi resiko tersebut, para praktisi perbankan mengusulkan untuk mensyaratkan hak mengembalikan (khiyar Syarat) ketika membeli barang kepada pihak pabrik dalam tempo tertentu. Hal ini dilakukan untuk mengetahui keinginan klien, apabila klien ingin membeli barang itu maka khiyar syarat itu pun dicukupkan sampai disitu namun apabila klien membatalkan maka pihak bank akan mengembalikan lagi ke pada pabrik. Namun disini pun masih ada resiko yang tinggi menyangkut biaya pengiriman dan pengadaan (biaya operasional)

\section{d. Bentuk Keempat}

Bank membeli barang yang biasa dibutuhkan pasar, atau karena ada permintaan dari salah seorang relasi bank. Setelah transaksi pembelian sempurna, kemudian pihak bank menjual kembali barang tersebut kepada relasi yang memesannya atau kepada siapa saja yang mau membelinya,dengan cara murabahah, dan pihak bank memberitahukan pihak

\footnotetext{
${ }^{1}$ Bank Dubai al-Islami. Fatawa syaiyah fi al-a'amal al-mashrhafiyah, (1985) hlm. 19

${ }^{2}$ M. Shalah as-Shawy. Musykilat al-istitsmar fi al-bunuk al-islamiyah. (Daru al-wafa'), hlm. 245
} 
pembeli tentang biaya awal dan biaya operasiobalnya secara total, dan meminta harga tambahan sebagai margin pihak bank. ${ }^{1}$

\section{e. Bentuk Kelima}

Pihak klien meminta bank untuk membelikan barang dengan sifat, tanda dan jumlah yang telah ditentukan, dan pihak nasabah berjanji (Al-Wa'du Muljam) akan membeli barang tersebut dengan cara angsuran apabila barang yang dipesannya tiba, dan ditambah margin sebagai keuntungan pihak bank. Disamping itu, ditentukan pula jumlah cicilan dan waktu pembayaran. Dan barang yang dipesan itu berada dibawah jaminan pihak bank sampai waktu penyerahan terlaksana, kemudian setelah itu pihak klien bertanggungjawab atas barangnya (setelah penyerahan). Dan apabila pihak klien membatalkan perjanjian untuk membeli barang tersebut, maka dia bertanggungjawab dan harus menanggung resiko dan kerugian yang ditanggung pihak bank akibat pembatalannya. Dalam arti lain: apabila pihak klien membatalkan pembelian maka pihak bank akan berusaha menjual pada pihak klien yang lainnya dan apabila biaya pengadaan dan operasionalnya tidak mencukupi dengan penjualan tadi maka pihak bank akan meminta ganti rugi kepada klien. Begitu pula sebaliknya apabila pihak bank membatalkan janjinya dalam mendatangkan barang sesuai pesanan maka pihak bank akan menanggung segala resiko dan kerugian yang ditanggung pihak klien. Ini berdasarkan kaidah memenuhi janji itu hukumnya wajib dan wajib pula menaggung resiko apabila tidak menepatinya. ${ }^{2}$

\section{f. Bentuk Keenam}

Khusus pada barang import. Pihak bank dan pihak klien telah sepakat melakukan transaksi jual beli, dan transaksi tersebut dilakukan ketika barang pesanan masih berada di tempat pabrik dan sebelum dikirimkan ke tempat pihak nasabah. Artinya: pihak bank telah mewakilkan orang lain untuk membeli barang di tempat pabriknya, dan setelahnya barang tersebut diterimanya dari pihak pabrik, pihak bank melakukan transaksi jual beli secara murabahah dan hal itu dilakukan sebelum barang tersebut dikirim ke

${ }^{1}$ Samy Mahmud, "Tathowur al-a'mal al-mashrhafiah bima yattafiku wa al-syari'ah al-islamiyah', hlm. 476-480

2 Yusuf Qardhawi. Bai' al-Murabahah li al-Aamir bi as-Syira'Kama Tajriyhi al-Masharif alIslamiyah. (T.tp: Maktabah Daru al-Qalam, 1994) hlm. 25 
tempat pihak nasabah, sehingga resiko pengiriman itu menjadi tanggung jawab nasabah. ${ }^{1}$

\section{g. Bentuk Ketujuh}

Pihak klien menghubungi pihak pabrik yang berada di luar negri secara langsung untuk mengirimkan barang yang dibutuhkannya atas nama bank. Dan ketika dokumen-dokumen pemesanan dan cukai pembayarannya (cara mendatangkan barang secara langsung tanpa melalui letter of credit/LC) sudah tiba, apabila pihak klien yang memesan tadi mau membeli barang tersebut dari pihak bank secara murabahah, maka pihak bank membayarnya langsung pada pihak pabrik kemudian bank melakukan tansaksi jual beli dengan pihak nasabah dan menyerahkan dokumen-dokumen tadi untuk menerima barangnya. Cara ini telah disetujui oleh badan syariah bait al-tamwil Kuwait dengan syarat barang tadi harus sudah menjadi milik bait al-tamwil dan berada dalam tanggungannya. ${ }^{2}$

\section{h. Bentuk Kedelapan}

Pihak bank menyuruh relasinya untuk membelikan barang tertentu untuk bank dari pasar dadakan/musiman. Dan setelah pihak bank memiliki barang tersebut, pihak bank menjualnya kepada pihak lain dengan khiyar syarat bagi pihak bank, dan dalam batas waktu yang telah ditentukan pihak bank berhak untuk membatalkan trasaksi tersebut (menggunakan khiyar syarat, hal itu terjadi apabila ada pihak lain mengajukan penawaran beli dengan harga yang lebih tinggi). Tapi semua itu dengan syarat pihak bank telah memiliki barang tersebut secara sah, dan ada dalam kekuasaannya dan siap diserahkan kepada pembeli kapan saja. ${ }^{3}$

\section{Keunggulan Transaksi MURABAHAH}

Setelah diperhatikan, uji coba investasi yang berlandaskan murabahah mendapat sambutan dan antusias tinggi dari para nasabah dan publik, sehingga skim ini menjadi trend yang paling banyak digemari dan dipraktekan dalam investasi perbankan, hal itu disebabkan oleh banyak faktor, salah satunya karena faktor tabi'at sosio kultural pertumbuhan ekonomi yang menuntut keberhasilan yang cepat dan mengahasilkan keuntungan yang banyak, dan sebagai respon pembuktian dan praktek alternatif dari praktek yang biasa dilakukan oleh

${ }^{1}$ Bait Attamwiel al-Kuwaity, 1983 . "Buyu' Al-amanah fi mizan al-syari'ah", hlm. 12

${ }^{2}$ Ibid. 25 
FITRAH Jurnal Kajian Ilmu-ilmu Keislaman

Vol. 02 No. 2 Desember 2016

perbankan konvensional, sehingga dengan adanya praktek murabahah, banyak nasabah perbankan konvensional mengalihkan kerjasamanya dengan perbankan Islam dengan cara ini.

Pada waktu bersamaan perbankan Islam mengalami kekurangan tenaga ahli yang menguasai bidang Fiqih dan operasional perbankan sekaligus (sehingga masih banyak praktek yang keluar dari jalur syariah), terlepas dari semua itu trasaksi murabah mempunyai keunggulan dan keuntungan ${ }^{1}$ tersendiri diantaranya:

a. Keuntungan yang akan diperoleh pihak bank lumayan dan masuk akal, khususnya dalam investasi jangka pendek. Sehingga mampu menarik simpati para nasabah untuk bergabung.

b. Bentuk transaksi ini relative sederhana, keuntungannya dihitung dari harga transaksi penjualan barang dan memudahkan klien untuk menentukan sisa keuntungan yang akan ia peroleh. Adapun status keduanya menjadi hubungan (krediotor dan debitor) semenjak penandatanganan transaksi jual beli.

c. Cara murabahah ini cocok untuk menjadi alat kredit perusahan komersil atau aktifitas perdangangan, dan mempunyai daya saing yang kuat terhadap sistem kredit yang berlaku pada perdagangan ribawi.

d. Hal yang lebih penting adalah bahwa persaingan real dan sesungguhnya antara kedua bank (syariah dan konvensional) terletak apada kemampuan dalam mensuplai dan membantu aktivitas ekonomi jangka pendek. Sebab dalam investasi jangka pendek inilah kerentanan unsur riba nampak dan jelas.

e. Banyak pihak nasabah ketika bekerjasama dengan bank syariah lebih tertarik kepada praktek murabahah daripada paktek lainnya seperti musyarakah. Hal ini dimaksudakan untuk menghindari intervensi bank terhadap keuangan pribada dan rahasia perusahaanya.

f. Minimnya resiko dalam investasi murabahah, karena keuntungan pihak bank telah ditentukan dari awal dan nasabah bebas dalam mengelola bisnisnya. Resiko yang mungkin terjadi apabila pihak klien lalai dalam pembayaran,untuk mengantisipasinya pihak bank meharuskan pihak suplayer menyimpan barang-barangnya pada gudang milik bank, atau dengan melakukan kontrol terpadu atas kinerja kliennya, atau menghubungkan

\footnotetext{
1 Fayah Addul Mun'im Hasanin, Mausu'ah al-Iqtishad al-Islami "Bay' al-murabahah fi almashraf al-islamiyah". (Darussalam 2009), jilid, 3, hlm. 377
} 
pelepasan barang dengan keaktifannya dalam membayar hutang yang sudah tiba waktunya

g. Dengan adanya pengalokasian dana bank Islam pada investasi murabahah, cara tersebut bisa menghasilkan surplus moneter (setoran rutin), sehingga bank bisa memenuhi kebutuhannya apabila para nasabahnya ingin menarik saldonya secara mendadak.

\section{Hukum Murabahah Perbankan dalam Persepsi Syariat}

Cara murabahah yang banyak dipraktekan perbankan Islam terdiri dari dua bagian; ${ }^{1}$

a. Pertama adalah: janji pihak nasabah untuk membeli, yang dikenal denga istilah permintaan untuk membeli (al-aamir bi al-siraa).

b. Kedua adalah: janji pihak bank untuk menjual.

Para ulama sepakat: bahwa pihak bank tidak boleh menjual barang dengan cara murabahah kepada pihak klien kecuali apabila bank telah memiliki barang tersebut dan ada dalam kekuasaanya, dan setelah itu, pihak bank boleh menjualnya pada pihak klien dengan cara murabahah. Hal itu diperlukan untuk menghindari dari jual beli yang tidak dibenarkan oleh syariah, dan agar tidak menjadi transaksi utang (kredit) yang berbunga karena adanya unsur waktu.

Dengan melihat praktek murabahah seperti tadi, lembaga syariat perbankan Islam dan beberapa ulama kontemporer menyatakan akan "kewajiban memenuhi janji"(iljam al-wa'ad/al-wa'd al-muljam) yang telah diikrarkan oleh kedua belah pihak. Hal tersebut dilakukan, untuk mengatur kerjasama perdagangan dan menjaga stabilitas perekonomian serta untuk menjaga kepentingan kedua belah pihak agar tidak mengalami kerugian. Adapun dasar legalitasnya tercantum dengan jelas didalam Al-qur'an dan Al-hadist serta kaidah maslahat (untuk memudahkan umat), seperti yang tercantum "Ambillah hukum yang memudahkan umat".

\section{Mekanisme Praktek Murabahah}

a. Fase-fase dan prosedur pelaksanaan transaksi murabahah dalam perbankan Islam

Secara formal, kerjasama investasi antar pihak bank dan pihak klien melalui cara murabahah harus melewati tiga fase ${ }^{1}$ yakni Fase study

\footnotetext{
${ }^{1}$ Ceccep Shalahuddin, M.A. Produk Investasi bank Islam Teori dan Praktek "Murabahah (jual beli dengan menentukan keuntukan dimuka". (Kairo: PAKEIS ICMI Orsat Kairo,2004) hlm. 80-81
} 
kelayakan, Fase pelaksanaan (pemberian dana), dan Fase pengontrolan dan evaluasi. Semua itu dilakukan secara berurutan, seperti di bawah ini:

1) Pihak klien mengajukan permintaan tertulis, dengan mengisi fomulir yang sudah disediakan untuk tujuan tersebut, didalamnya tertulis permintaan untuk membelikan barang yang sudah ditentukan sifat-sifat (tanda) nya, jumlah dan batas waktu yang diperlukan, juga dikutsertakan bersama formulir tadi daftar harga atau berkas kwitansi pembelian yang lalu.

2) Kemudian pihak bank mempelajari permintaan tersebut dengan teliti dari berbagai dimensi, antara lain:

a) Dimensi yang menyangkut klien, meliputi karakternya berdasarkan penyelidikan lapangan, Reputasi dan citra kerja sebelumnya, status perpajakannya, Kepatuhannya ketika berinteraksi dengan bank lain dan posisi finansialnya dan kemampuan pembayaran cicilan ketika waktu pembayaran tiba.

b) Dimensi yang menyangkut studi kelayakan ekonomi barang/komoditi, meliputi: Studi tentang kondisi permintaan dan suplay barang serta perkembangannya dimasa yang akan datang, Kondisi umum tetang pasar dan masa depannya, Strategi marketing dan penjualannya, dan Sistem yang mengatur peredaran barang (dari segi harga, jumlah, peraturan import dan lainnya), dan strata keuntungan yang akan dihasilakn dari penjualan komoditi tersebut.

c) Dimensi yang menyangkut operasi pelaksanaan, meliputi biaya operasi transaksi, waktu operasi, keuntungan yang akan diperoleh pihak bank, harga penjualan pada pihak klien, Cara pembayaran dan batas waktunya, Jaminan yang diberikan pihak klien, Jumlah cicilan yang akan dibayar pihak klien, Jumlah keseluruhan dana yang dikeluarkan pihak bank untuk membiayai operasi dan cara pembayarannya.

3) Apabila pihak bank merekomendasi proyek tersebut untuk dilaksanakan sesuai denga aturan operasionalnya, maka pihak klien harus menandatangani transaksi janji untuk membeli, dalam transaksi

${ }^{1}$ Fayah Addul Mun'im Hasanin. Mausu'ah al-Iqtishad al-Islami "Bay' al-murabahah fi almashraf al-islamiyah".(Darussalam2009) jilid, 3, hal 383-385 
tersebut ditentukan tempat dan waktu penerimaan, laporan jumlah biaya pembelian, jaminan yang diminta dan lainnya, kemudian pihak klien membayar uang muka pada pihak bank, dan pihak klien wajib mematuhi semua janji yang sudah ditandatangani dan menaggung semua kerugian akibat ingkar janji atau pembatalan kesepakatan.

4) Kemudian pihak bank berusaha mendatangkan barang baik secara import atau membeli dari pasar local, dan bank mengeluarkan cek untuk sebagai ganti pembayaran harga barang (atau dengan cara pebayaran lainnya yang sesuai) untuk kepentingan suplayer, dan utusan bank memberikannya kepada suplayer tersebut untuk ditukar dengan kwitansi pembelian terakhir untuk kepentingan bank, dan penyerahan barang, dan untuk barang import ketika import berlangsung telah lengkap dokumen-dokumen disertai harga keseluruhan barang. Yang terpenting penandatanganan barang tersebut atas nama bank, sebagaimana bank pun bertanggungjawab membiayai ongkos-ongkos lainnya; seperti: tarif bea cukai, biaya muatan dan asuransi.

5) Setelahnya barang berada dibawah kekuasaan bank, pihak bank boleh melangsungkan transaksi jual belinya dengan pihak klien, dalam transaksi tersebut ditentukan jumlah hutang yang harus dibayar oleh pihak klien, waktu dan cara pembayaran cicilan, penyerahan jaminan yang diminta dan lainnya. Berdasarkan akan transaksi tersebut pihak klien berhak menerima barang tersebut pada tempat yang telh disepakati dan dengan sifat (tanda) yang telah ditentukan.

\section{Harga dan Dasar penentuan prosentase keuntungan}

Keuntungan yang diperoleh bank dari hasil transaksi murabahah ditentukan oleh jumlah biaya yang dikeluarkan bank untuk membiayai transaksi yang disepakati bersama, dan juga beberapa faktor lainnya yang ikut menentukan keuntungan tersebut, yaitu;

a. Kecepatan perputaran barang.

b. Jumlah dana yang dialokasikan pihak bnak dalam investasi murabahah.

c. Jumlah uang muka yang dibayarkan pihak klien.

d. Persentasi keuntungan yang berlaku di pasar. (sebisanya lebih rendah dari suku bunga kredit) 
FITRAH Jurnal Kajian Ilmu-ilmu Keislaman

Vol. 02 No. 2 Desember 2016

e. Strata keuntungan yang harus diperoleh pemegang simpanan investasi. ${ }^{1}$

Berbeda dengan bank konvensional, dalam mekanisme murabahah nasabah dapat mengetahui total harga barang sebelumnya, dimana hal ini tidak akan diketahui dalam pembiayaan berbasis bunga. Dalam murabahah, tampaknya faktor yang mempengaruhi besarnya mark-up kebutuhan bank syariah untuk memeperoleh keuntungan rill, inflasi, suku bunga berjalan, kebijakan moneter, marketabilitas barang-barang murabahah serta tingkat laba yang diinginkan dari barang tersebut. Dengan demikian mark-up dalam murabahah bisa saja lebih tinggi atau lebih rendah dari suku bunga. Karena selama ini kalangan awam menilai yang namanya lembaga syariah selalu identik dengan harga murah. Sehingga jika terjadi penjualan barang oleh bank syariah dengan harga lebih tinggi dibanding harga jual bank tidak syariah, maka bank syariah dinilai lebih tidak islami. Padahal, suatu ketika memang bisa terjadi demikian adanya. ${ }^{2}$

\section{Uang muka}

Dalam jual beli ini bank dibolehkan meminta nasabah untuk membayar uang muka saat menandatangani kesepakatan awal pemesanan. Besar jumlah uang muka ditentukan berdasar kesepakatan dan merupakan bagian dari pembayaran hutang Jika nasabah kemudian menolak membeli barang tersebut, biaya riil bank harus dibayar dari uang muka tersebut. Jika nilai uang muka kurang dari kerugian yang harus ditanggung oleh bank, maka bank dapat meminta kembali sisa kerugiannya kepada nasabah namun apabila uang muka tersebut lebih besar dari jumlah kerugian maka bank harus mengembalikan kelebihannya kepada nasabah. ${ }^{3}$ Jika uang muka memakai kontrak 'urbun ${ }^{4}$ sebagai alternatif dari uang muka, maka:

a. Jika nasabah memutuskan untuk membeli barang tersebut, ia tinggal membayar sisa harga.

\footnotetext{
${ }^{1}$ Ibid., hlm. 86-87

2. Muhammad. 2004. Teknik Perhitungan Bagi hasil dan Profit Margin Pada Bank Syari'ah. Yogyakarta: UII press, hal.103

3. Fatwa Dewan Syari'ah Nasional Majelis Ulama Indonesia no: 13/DSN-MUI/LX/2000, tentang Pembayaran Uang Muka dalam Murabahan.

4. Abdul Hamid Mahmud al-BU'ali. 1991. Al-Istitsmar wa al-Riqabah al-Syar'iyah fi al-Bunuk wa al-Muassasat al-Islamiyah. Turki: Bank Faishol Turk, hal. 116
} 
b. Jika nasabah batal membeli, uang muka menjadi milik bank maksimal sebesar kerugian yang ditanggung oleh bank akibat pembatalan tersebut; dan jika uang muka tidak mencukupi, nasabah wajib melunasi kekurangannya

\section{Jaminan dalam murabahah}

Bank diperbolehkan meminta jaminan dari nasabah dan menyuruh nasabah untuk memepersiapkan jaminan yang bisa dipegang, ${ }^{1}$ hal ini dikarenakan hubungan yang jelas antara kedua belah pihak yaitu; hubungan hutang piutang (indebtedness). Oleh sebab itu, pihak bank berusaha untuk mengamankan posisi finansialnya sebagai langkah hati-hati untuk menghindari nasabah nakal yang tidak menepati janji, maka diperlukanlah yang namanya jaminan.

\section{Diskon dalam murabahah}

Harga (tsaman) dalam jual beli adalah suatu jumlah yang disepakati oleh kedua belah pihak, baik sama dengan nilai (qîmah) benda yang menjadi obyek jual beli, lebih tinggi maupun lebih rendah. Adapun harga dalam jual beli murabahah adalah harga beli dan biaya yang diperlukan ditambah keuntungan sesuai dengan kesepakatan. Jika dalam jual beli murabahah LKS mendapat diskon dari supplier, harga sebenarnya adalah harga setelah diskon; karena itu, diskon adalah hak nasabah. ${ }^{2}$ Jika pemberian diskon terjadi setelah akad, pembagian diskon tersebut dilakukan berdasarkan perjanjian (persetujuan) yang dimuat dalam akad. Begitu juga dalam akad, pembagian diskon setelah akad hendaklah diperjanjikan dan ditandatangani.

\section{Potongan pelunasan dalam murabahah}

Jika nasabah dalam transaksi murabahah melakukan pelunasan pembayaran tepat waktu atau lebih cepat dari waktu yang telah disepakati, LKS boleh memberikan potongan dari kewajiban pembayaran tersebut, dengan syarat tidak diperjanjikan dalam akad. Adapun besar potongan diserahkan pada kebijakan dan petimbangan LKS yang bersangkutan. ${ }^{3}$

\footnotetext{
1. Fatwa Dewan Syari'ah Nasional Majelis Ulama Indonesia no: 04/DSN-MUI/IV/2000, tentang Murabahah.

2 Fatwa Dewan Syari'ah Nasional Majelis Ulama Indonesia no: 16/DSN-MUI/IX/2000, tentang Diskon Dalam Murabahah

3 Fatwa Dewan Syariah Nasional Majelis Ulama Indonesia no. 23/DSN-MUI/III/2002 tentang potongan pelunasan dalam murabahah
} 
FITRAH Jurnal Kajian Ilmu-ilmu Keislaman

Vol. 02 No. 2 Desember 2016

\section{Hutang dalam murabahah}

Secara prinsip, penyelesaian hutang nasabah dalam transaksi murabahah tidak ada kaitannya dengan transaksi lain yang dilakukan nasabah dengan pihak ketiga atas barang tersebut. Jika nasabah menjual kembali barang tersebut dengan keuntungan atau kerugian, ia tetap berkewajiban untuk menyelesaikan hutangnya kepada bank. Jika nasabah menjual barang tersebut sebelum masa angsuran berakhir, ia tidak wajib segera melunasi seluruh angsurannya.

Jika penjualan barang tersebut menyebabkan kerugian, nasabah tetap harus menyelesaikan hutangnya sesuai kesepakatan awal. Ia tidak boleh memperlambat pembayaran angsuran atau meminta kerugian itu diperhitungkan. ${ }^{1}$

\section{Penundaan pembayaran oleh nasabah mampu}

Penundaan pembayaran dengan sengaja oleh nasabah/klien yang mampu tidak dibenarkan, dan LKS atau bank berhak memberikan sanksi terhadap nasabah mampu yang nakal, tidak mempunyai i'tikad baik ini. Sanksi didasarkan pada prinsip ta'zir, yaitu bertujuan agar nasabah lebih disiplin dalam melaksanakan kewajibannya. Sanksi dapat berupa denda sejumlah uang yang besarnya ditentukan atas dasar kesepakatan dan dibuat saat akad ditandatangani. Selanjutnya dana yang berasal dari denda diperuntukkan sebagai dana sosial. ${ }^{2}$

\section{Bangkrut dalam murabahah}

Apabila nasabah yang melakukan kerjasama murabahah dengan bank Islam mengalami kebangkrutan atau pailit, maka bagi bank untuk menangguhkan hutangnya hingga dia mampu membayar kembali atau sesuai dengan kesepakatan.

\section{Resiko dalam Murabahah}

Di dalam pembiayaan murabahah tidak lepas dari resiko-resiko yang harus ditanggung diantaranya:

a. Resiko yang terkait dengan barang

Bank membeli barang-barang yang dipesan oleh nasabahnya maka secara teoritis bank akan terkait dengan resiko kehilangan atau kerusakan dari

1 Fatwa Dewan Syari'ah Nasional Majelis Ulama Indonesia no: 04/DSN-MUI/IV/2000, tentang Murabahah.

2 Fatwa Dewan Syari'ah Nasional Majelis Ulama Indonesia no: 17/DSN-MUI/IX/2000, Tentang Sanksi Atas Nasabah mampu yang menunda-nunda Pembayaran 
barang tersebut dari saat pembelian hingga saat penyerahan barang. Dalam transaksi murabahah bank syariah diwajibkan untuk menyerahkan barang kepada nasabah dalam kondisi yang baik, bahkan nasabah bisa menolak barang yang rusak, kurang jumlahnya atau yang tidak sesuai dengan spesifikasinya. Maka untuk itu bank sudah menyiapkan asuransi dan klausal kontrak yang bisa menghindarkan dari hal-hal tersebut.

b. Resiko yang terkait dengan nasabah

Apabila nasabah membatalkan trasaksi murabahah, maka dalam pada prakateknya bisa dihindari dengan pembayaran uang di muka, jaminan. Jaminan pihak ketiga dan klausal kontrak.

c. Resiko yang terkait dengan pembayaran

Keterlambatan pembayaran dalam transaksi murabahah memang biasa terjadi, maka untuk menghindari itu bank melakukan cara janji tertulis jaminan, jaminan pihak ketiga, klausal kontrak dengan menyatakan semua itu harus disimpan di bank sampai nasabah menepati pembayarannya. Apabila keterlambatan tersebut diluar kemampuan nasabah maka bank secara moral berkewajiban menjadwal ulang hutang. Namun jikalau ini disebabkan nasabah nakal yang mampu namun menunda-nunda pembayaran, maka akan dijatuhkan padanya sanksi. ${ }^{1}$

\section{Penyimpangan-penyimpangan yang Terjadi dalam Operasional Murabahah}

Wajar pabila banyak perspektif negatif yang ditujukan oleh masyarakat awam kepada Bank Syariah. Sejauh ini mayoritas portofolio pembiayaan oleh Bank Syariah didominasi oleh pembiayaan Murabahah. Umumnya mereka mengatakan operasional bank syariah tidak berbeda dengan bank konvensional. Hanya saja jika di Bank Konvensional menerapkan sistim bunga, maka di bank syariah dirubah dengan istilah margin. Apa memang perbedaannya hanya sekedar bunga dan margin?

Sepintas memang ada kemiripan antara pembiayaan Murabahah di Bank Syariah dan kredit pembelian barang di Bank Konvensional. Nasabah datang ke Bank untuk menyampaikan keinginannya membeli suatu barang dengan meminta bantuan dana kepada Bank. Bank lalu menganalisa kemampuan Nasabah. Jika dirasakan Nasabah layak untuk menerima bantuan dari Bank, maka Bank akan menyalurkan dananya kepada Nasabah. Yang satu

\footnotetext{
1 Anita Rahmawaty. 2007. Ekonomi syari'ah; Tinjauan Kritis Produk Murabahah Dalam Perbankan Syari'ah di Indonesia. Jurnal Ekonomi Islam. La-Raiba. Hal. 196-197
} 
mensyaratkan tambahan bunga pada pengembalian hutangnya, sedangkan yang lain mem-mark up harga beli atas penjualan barangnya kepada Nasabah. Nasabah lalu membeli barang tersebut untuk keperluannya. Selanjutnya Nasabah secara rutin membayar angsuran kepada Bank. "Sama saja!", demikian mungkin pendapat awam mengenai kedua praktek perbankan tersebut. Allah Swt., berfirman yang Artinya: Benarkah sama antara pembiayaan Murabahah di bank Syariah dan pemberian kredit di Bank Konvensional? Bukankah Allah telah berfirman "Allah telah menghalalkan jual beli dan mengharamkan riba" (QS. 2:275).

Sebagaimana kita ketahui, dalam skim Murabahah fungsi Bank adalah sebagai Penjual barang untuk kepentingan Nasabah, dengan cara membeli barang yang diperlukan Nasabah dan kemudian menjualnya kembali kepada Nasabah dengan harga jual yang setara dengan harga beli ditambah keuntungan Bank dan Bank harus memberitahukan secara jujur harga pokok Barang berikut biaya yang diperluan dan menyampaikan semua hal yang berkaitan dengan pembelian Barang kepada Nasabah.

Akan tetapi dalam praktek operasionalnya sering terjadi beberapa penyimpangan yang biasanya dilakukan oleh oknum pegawai pada beberapa Bank Islam, antara lain:

a. Sebagai Penyedia Barang dalam prakteknya Bank Syariah kerap kali tidak mau dipusingkan dengan langkah-langkah pembelian Barang. Karenanya Bank Syariah menggunakan media "akad Wakalah" dengan memberikan kuasa kepada Nasabah untuk membeli barang tersebut. Langkah pemberian "Wakalah kepada Nasabah" inilah yang oleh sebagian akademisi dianggap bahwa Bank Syariah terkadang kurang bijak dan tidak hati-hati menerapkan media "Wakalah pembelian Barang" ini. Karena Fatwa MUI No.04/DSNMUI/IV/2000 tanggal 1 April 2000 (26 Dzulhijah $1420 \mathrm{H}$ ) telah menetapkan bahwa jika Bank hendak mewakilkan kepada Nasabah untuk membeli barang dari pihak ketiga, maka akad jual beli murabahah harus dilakukan setelah barang secara prinsip menjadi milik Bank. Dengan kata lain, pemberian kuasa (Wakalah) dari Bank kepada Nasabah atau pihak ketiga manapun, harus dilakukan sebelum Akad Jual beli Murabahah terjadi. Dalam kenyataannya, Akad Murabahah sering kali mendahului pemberian Wakalah dan dropping dana pembelian barang. Bagaimana mau dikatakan 
barang telah menjadi milik Bank, jika droping dana pembelian barang saja dilakukan setelah akad Murabahah ditanda-tangani.

b. Membayar harga barang kepada pihak klien (pemesan barang), baik itu dalam pembayaran cash atau transfer pada nomor rekening pemiliknya, dan mencukupkan dengan adanya laporan kwitansi pembelian dari pihak suplayer (sumber barang/ pabrik/ pasar) atas nama bank dengan harga barangnya. Hal itu tanpa melalui transaksi jual beli langsung antara pihak bank dan pihak sumber barang, dan tanpa ada wakil bank yang menerima penyerahan barang atas nama pihak bank yang akan menyerahkan barangnya kepada pihak klien sebagai pemesan barang.

c. Penandatanganan transaksi jual beli dengan cara murabahah bersamaan waktunya dengan penandatanganan transaksi perjanjian untuk membeli barang (fase awal). Hal ini dilangsungkan ketika barang yang dipesannya belum ada dan bank pun belum memilikinya.

d. Pihak bank melepas tanggung jawabnya dari berbagai resiko operasional transaksi, barang pesanan dianggap aman padahal barang tersebut masih dalam proses pengiriman dan pihak klien menerima barang tersebut saat kedatangannya lansung dari pihak pabrik, dan kebijakan bank tersebut direkomendasikan oleh pihak klien dengan membebaskan pihak bank atas kecacatan yang dikirim. Berdasarkan praktek tadi maka jelaslah bahwa pihak klien mempunyai hubungan langsung dengan sumber barang/spliyer dan ia juga menentukan segalanya, disamping pihak bank tidak bertanggungjawab atas kemungkinan keterlambatan pengiriman juga tidak betanggung jawab atas kemungkinan tidak dikirimnya barang oleh suplayer, bahkan pihak bank tidak diwajibkan membayar ganti rugi kepada pihak klien yang disebabkan oleh keterlambatan atau tidak dikirimnya barang. Dari transaksi tadi terjadi ketimpangan hukum, dimana pihak klien diwajibkan mematuhi janjinya untuk membeli, dan sebaliknya bank tidak diwajibkan untuk memetuhi janjinya, yaitu menanggung resiko akibat keterlambatan, tidak dikirimnya barang atau kecacatan pada barang, bahkan pada riilnya bank bukan sebagai penjual hakiki yang mencari keuntungan dengan jual beli tapi sekedar pemberi kredit yang mengambil keuntungan dari bunganya, dan hanya mau mengambil keuntungan dan tidak mau mengambil resiko kerugiannya, padahal ada sebuah kaidah syri'at yang mengatakan "setiap amanat itu harus ada jaminannya dan setiap 
keuntungan itu harus siap menanggung resiko kerugiannya" (al-kharaj bi aldhaman wa al-ghanan bi al-garam).

e. Pemberian dana untuk transaksi proyek jasa pelayanan dengan cara murabahah, seperti membayar kredit cukai, khususnya pada kondisi dimana cukainya sangat mahal atau bahkan lebih mahal dari barangnya sendiri, atau melakukan transaksi murabahah pada proyek pemasangan alat tertentu (assembling) dan lainnya semua itu tidak perbolehkan karena pakter murabahah hanya terbatas pada bentuk barang saja dan tidak boleh pada jasa pelayanan.

f. Pemberian dana pada proyek kerjasama lisensi (pembukaan cabang) antara wakil local dan pihak pemilik lisensi (pabrik/ hak cipta) barang, dimana transaksinya dilakukan hanya dengan berdasarkan bukti pembayaran atau dokumen transaksi yang diserahkan wakil local pada pihak bank.

g. murabahah atas utang piutang yang disebabkan murabahah sebelumnya, bentuknya adalah pihak bank menggantikan posisi pihak kreditor pertama dalam melaksanakan pembayaran hutang dan menuntut haknya dalam mendapat keuntungan sebagai imbalan pemberian dana dengan penguluran waktu.

\section{PENUTUP}

Praktek investasi jangka pendek murabahah merupakan salah satu intstrumen penting dalam transaksi di perbankan Islam. Transaksi ini memungkin untuk pengadaan barang bagi pengusaha yang kurang mempunyai dana, selain sebagai suatu skim yang memberikan keuntungan kepada bank Islam, tidak memiliki resiko tinggi dan sebagai alat peredam ditengah praktek ribawy yang terjadi pada invesatasi jangka pendek.

Hanya dalam prakteknya harus dilakukan dengan jeli dan pengawasan yang ketat agar tidak terjadi penyelewengan-penyelewengan yang jauh dari syariah. Oleh karena itu untuk kemajuan perekonomian Islam dibutuhkan pelatihan pemahaman teori dan praktek secara bersamaan sehingga tidak ada yang bisa mengelabui pihak bank dengan trik-trik canggih di lapangan. 


\section{DAFTAR PUSTAKA}

Al-Misri, Rafi Yunus, Al-Jami' fi Ushul ar-Riba, ( Damaskus: Dar al-Qalam, 1991)

Al-Misri, Rafi Yunus, Al-Majmu' fi al-Iqtishad al-Islamiy, (Syuria: Daru al-Maktabi , 2006)

Al-Qardhawi, DR.Yusuf, , Bai' al-Murabahah li al-Aamir bi asy-Syira' Kama Tajriyah al-Masharif al-Islamiyah, t.tp: (Kuwait: Maktabah Daru al-Qalam, 1415 H/1994 M.)

Al-Shawy, Muhammad Shalah. Musykilat al-Istitsmar fi al-Bunuk al-Islamiyah wa Kaifa 'Alajaha al-Islam. (Al-Mansurouh: Daru al-wafa', 1990)

Anita Rahmawaty, Ekonomi syariah; $T$ injauan kritis Produk Murabahah dalam perbankan syariah di Indonesia, Jurnal Ekonomi Islam La-Raiba. Desember 2007

Bait attamwiel al-kuwaity, al-Fatawa al-Syar'iyah fi al-Masa'il al-Iqtishadiyah .(2/25), (Kuwait: 1987)

Buyu' Al-amanah fi Mizan al-Syariah, (kuwait: 1983)

Bank Dubai al-Islami. Fatawa Syaiyah fi al-A'amal al-Mashrhafiyah, (Dubai: 1985)

Hamud, Samy, Tathwir al-A'mal al-Mashrhafiah bima Yattafiku wa al-Syariah alIslamiyah, (Kairo: Darul al-attihad al-arabi, 1976)

Hasanin, Fayad Addul Mun'im,. Mausu'ah al-Iqtishad al-Islami “Bay' al-murabahah fi al-mashraf al-islamiyah". jilid, 3 (Kairo: Darussalam, 2009)

Hendry, Arison, Perbankan Syariah: Perspektif Praktisi, (Jakarta: Muamalat Institute, 1999)

Mannan, Muhammad Abdul, (terj), M, Nastangin, Teori dan Praktek Ekonomi Islam, (Yogyakarta: Dana Bakti Wakaf, 1995)

Muhammad. Teknik Perhitungan Bagi hasil dan Profit Margin Pada Bank Syariah. ( Yogyakarta: UII press, 2004)

Perwaatmadja, ,Drs. H. Karnaen, MPA. Antonio, H. Muhammad Syafi'I, M.Ec.. Apa dan Bagaimana Bank Islam. Yogyakarta: Dana Bhakti Wakaf, 1992) 
FITRAH Jurnal Kajian Ilmu-ilmu Keislaman

Vol. 02 No. 2 Desember 2016

Robbiyanto "Sektor Syariah Rahmat Bagi Sektor Usaha". Makalah dalam Seminar Nasional dan Launching Jurnal Lebi 2007, Yogyakarta, 17 Desember 2007

Saeed, Abdullah, Islamic Banking and Interest, A Study of Prohibition of Riba and its Contemporary Interpretation, (Leiden : E.J. Brill, 1996).

Shalahuddin, Ceccep, M.A, Produk Investasi Bank Islam Teori dan Praktek "Murabahah (jual beli dengan menentukan keuntukan dimuka". (Kairo: PAKEIS ICMI Orsat Kairo, 2005)

Sjahdeini, Sutan Remy.. Perbankan dan Kedudukannya dalam Tata Hukum Perbankan Indonesia, (Jakarta: Pustaka Utama Grafiti, 1999)

Tazkia Institute, Murabahah, Makalah disampaikan pada Program Pendidikan dan Pengembangan SDM Bank Mu'amalah. 14 Mei 1999

Zulfikar Nazara. "Perkembangan Bank Syariah". Makalah dalam Seminar Nasional dan Launching Jurnal Lebi 2007, Yogyakarta, 17 Desember 2007 